\title{
Analysis of capacity of information technology of college teachers
}

\author{
Wang Siyan \\ Zhengzhou Shengda economics trade and Management College \\ Anthea16@126.com
}

\begin{abstract}
With the development and wide use of information technology, the change of the new century students and diversity of their psychological demand and other factors has brought new challenges to educators. In order to more clearly understand the current situation of teachers' ability of information technology, in this study, through an extensive survey, the technical ability of college liberal arts teachers, demands of the ability and their ideal training methods are analyzed in detail, only to find their ability of information technology, especially the research ability in this field, is eager to be improved. Therefore some constructive suggestions are put forward to related departments.
\end{abstract}

Keywords- informatization; teachers; technical ability

\section{INTRODUCTION}

Since the beginning of the twenty-first Century, information technology has penetrated into all aspects of economic development and social life style and learning style is undergoing profound changes, universal education, quality education, individualized learning and lifelong learning has become an important feature of educational development in the information age. Facing the increasingly fierce competition in overall national strength, there is a universal concern to the important role the education informatization has played in improving national quality and strengthening national innovation ability. "National plan on medium and long-term educational reform and development (2010-2020)" clearly pointed out: "the information technologies have a revolutionary impact on the development of education, so it must be attached great importance to." Universities have become an important component of a national science and technology innovation system and an innovation base. Therefore, the teaching and the scientific research work in colleges and universities, plays a more and more important role not only in the field of education, but also in science and technology, economy, and the social development. So the liberal arts teachers, as the main force in the humanities research, need to have not only professional skills, profound cultural accomplishment, but also the knowledge structure of multi-disciplines and the ability of information technology. Only in this way, can they promote the development of related research and the innovation of science and technology.

\section{LITERATURE REVIEW}

Information technology capability refers to the ability to obtain, transfer, store, process and analyze information technology, [1]in particular, is to have good information consciousness, and has the ability to quickly collect, collate, process, create and use information, namely the ability of good information literacy, and to select useful information effectively and from the wealth of information. [2]The information technology applied in the field of education usually refers to multimedia technology, digital video and audio technology, satellite TV broadcasting technology, artificial intelligence technology, network technology and virtual technology, used in classroom teaching and service support, student learning and school management and service support.

Currently, the related research varies. Gou,from the angle of information evaluation, on the foundation of analysis of the domestic and foreign existing assessment mode, put forward the diagnostic appraisal method with the features of maturity model to evaluate educational technology ability of colleges and universities; [3]Zhang Lianalyzed restricting factors to the teachers' information accomplishment; [4]From the renewal of educational ideas Wang Qinglin discussed the reflections on how college teachers adapt to the development of education information technology. [5]Chen Kaiquan, from the development of the school-based teaching organization and system, from the scientific perspective of information and learning, discussed the difficulties and Countermeasures of the development of University Teachers' Teaching. [6]Lu Hongxia, from the perspective of the theory of action learning, studied college teachers' educational technology training mode. [7] Fu Zhongyong, proposed the macro and micro problems and misunderstandings of information teaching ability of teachers. [8]Fang Mingjian, from the perspective of learning theory, studied the strategy cultivation of teachers' information ability, that is, the transformation from policy-driven passive learning to technology-driven, development-driven active learning. [9]Wang Wenjun, from the angle of the system of teachers' knowledge, discussed teachers' practical information ability. [10]The researches mainly focus theoretically on how to view, valuate and train teachers' capacity of information technology. But what is the current situation of teachers' capacity of information technology? What ability do they have? What do they still need to know? With such puzzles, a survey was conducted among liberal arts teachers in some universities and colleges in Henan Province.

\section{A SURVEY OF INFORMATION TECHNOLOGY ABILITY}

Questionnaire was designed into three parts: the basic status of teachers investigated, their information capacity and demands. the returned questionnaires were collated with an outcome of 222 effective questionnaires. 
A.

Analysis of basic conditions

The first part is the basic information of the teachers investigated as follows.

TABLE I. DISCIPLINE CLASSIFICATION

\begin{tabular}{l|llllll}
\hline discipline s & law & linguistics & literature & management & other & total \\
\hline number & 6 & 64 & 26 & 84 & 42 & 222 \\
percentage $\%$ & 2.7 & 28.8 & 11.7 & 37.8 & 18.9 & 100
\end{tabular}

Seen from table 1 , teachers involved are mainly from Linguistics and management, so the professional analysis followed will be comparatively conducted between the both.

TABLE II. TEACHING EXPERIENCE (YEARS) OF THE TEACHERS INVESTIGATED

\begin{tabular}{c|lllll}
\hline teaching experience & \multicolumn{1}{|c|}{$\mathbf{1 - 3}$} & $\mathbf{4 - 7}$ & $\mathbf{8 - 1 2}$ & \multicolumn{1}{c|}{ 13 } & total \\
\hline number & 52 & 84 & 50 & 36 & 222 \\
percentage $\%$ & 23.4 & 37.8 & 22.5 & 16.2 & 100
\end{tabular}

From table 2, we know among all the teachers investigated, teachers with a teaching experience of 4-7 years take up the largest part, accounting for $37.8 \%$.

TABLE III. EDUCATION OF TEACHERS INVESTIGATED

\begin{tabular}{c|llll}
\hline education & bachelor & master & doctor & total \\
\hline number & 46 & 174 & 2 & 222 \\
percentage \% & 20.7 & 78.4 & 0.9 & 100
\end{tabular}

The largest proportion is bachelor, which is also a reflection of the current structure of teachers in universities and colleges of China. And the following comparison goes between bachelors and masters for the number of doctors is two small without any statistical significance.

TABLE IV. PROFESSIONAL TITLE

\begin{tabular}{c|llll}
\hline professional title & Primary & intermediate & high & total \\
\hline number & 54 & 116 & 52 & 222 \\
percentage $\%$ & 24.3 & 52.3 & 23.4 & 100
\end{tabular}

The second part is about information capacity, mainly including four parts: one is the basic operation of office software, a second is the use of the Internet search, network platform and network communication tools, a third is editing, designing and producing of some audio and video files, pictures and animations, a fourth is the establishment, retrieval and use of different corpuses. For each part, there are 4-7 questions to specify the related capacity. The outcome is as shown in table 5.

TABLE V. THE CAPACITY OF SPECIFIC INFORMATION

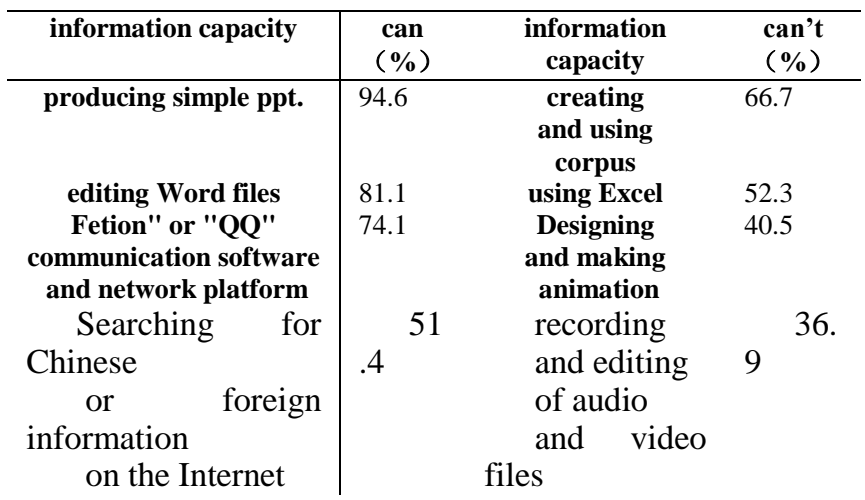

The survey among teachers found that, in the four categories of all of the information capacities, the one of commonly used office software comes first, especially simple production capacity of PPT courseware has spread to $94.6 \%$ of the teachers, capacity to edit the word file has spread to $81.1 \%$, while also as the office basic ability, the simple operation of Excel and transformation of different formats is relatively weak. In second place is the ability to use the network, and relatively $72.1 \%$ and $54.2 \%$ of teachers use QQ, Fetion network software or blogging network platform in their work. The weakest one is the ability of the establishment and application of database, teachers without the ability accounting for $66.7 \%$. Teachers who can't use Excel take up more than half.

The third part of the questionnaire is the information ability that currently teachers want to learn most and their favorite training method.

TABLE VI. INFORMATION CAPACITY TEACHERS WANT TO LEARN MOST

\begin{tabular}{c|l}
\hline $\begin{array}{c}\text { Information ability } \\
\text { Design and production of animation }\end{array}$ & $\begin{array}{c}\text { proportion of people } \\
\text { who want to learn } \\
(\%)\end{array}$ \\
\hline $\begin{array}{c}\text { files } \\
\text { recording and editing of Audio and video }\end{array}$ & 45 \\
$\begin{array}{c}\text { establishment of a small database } \\
\text { Transformation between different file } \\
\text { formats }\end{array}$ & 37.8 \\
\end{tabular}

TABLE VII. PROPORTION OF VARIOUS SELECTIONS ABOUT THE BEST WAY OF TRAINING

\begin{tabular}{|c|c|c|c|c|c|c|}
\hline $\begin{array}{c}\text { order } \\
\text { of } \\
\text { their } \\
\text { choices }\end{array}$ & $\begin{array}{l}\text { full- } \\
\text { time }\end{array}$ & $\begin{array}{c}\text { in- } \\
\text { service } \\
\text { online }\end{array}$ & experts & $\begin{array}{l}\text { research- } \\
\text { driven }\end{array}$ & $\begin{array}{c}\text { periodical } \\
\text { training }\end{array}$ & $\begin{array}{c}\text { self- } \\
\text { taught }\end{array}$ \\
\hline $\begin{array}{c}\text { first } \\
\text { choice }\end{array}$ & 29.3 & 25.3 & 20 & 20 & 5 & 0 \\
\hline $\begin{array}{l}\text { second } \\
\text { choice }\end{array}$ & 13.2 & 7.4 & 20.6 & 20.6 & 32.4 & 5.9 \\
\hline $\begin{array}{l}\text { third } \\
\text { choice }\end{array}$ & 10.3 & 23.5 & 22.1 & 16.2 & 14.7 & 13.2 \\
\hline
\end{tabular}

B.

The relationship between kinds of information skills and professional qualifications, experience and professional title

First of all, let's have a statistic to see if there is any professional difference in various information technology skills.

TABLE VIII. RELATIONSHIP BETWEEN VARIOUS INFORMATION ABILITY AND PROFESSIONS

\begin{tabular}{|c|c|c|c|c|}
\hline \multirow[t]{2}{*}{ Information ability } & \multicolumn{2}{|c|}{$\begin{array}{c}\text { Linguistics } \\
(\%)\end{array}$} & \multicolumn{2}{|c|}{$\begin{array}{c}\text { Management } \\
(\%)\end{array}$} \\
\hline & can & Can't & can & Can't \\
\hline $\begin{array}{c}\text { Fetion" or "QQ" } \\
\text { communication software } \\
\text { and network platform }\end{array}$ & 74.4 & 4.7 & 48.8 & 9.7 \\
\hline $\begin{array}{c}\text { establishment of a small } \\
\text { database }\end{array}$ & 3.2 & 45.2 & 7.5 & 12.5 \\
\hline $\begin{array}{l}\text { Excel software and its } \\
\text { statistics using }\end{array}$ & 51.6 & 22.6 & 65 & 10 \\
\hline animation design & 12.5 & 56.3 & 17.1 & 36.6 \\
\hline $\begin{array}{l}\text { Video and audio file } \\
\text { recording and editing }\end{array}$ & 41.4 & 25 & 17.1 & 41.5 \\
\hline
\end{tabular}

Of all the four above mentioned categories of information technology ability (as in table VIII), linguistic teachers do better than management teachers in commonly used office software skills, audio and video files recording and editing and network using, while in the aspects such as establishment and use of a small database, designing of 
animations, Excel and its statistic using, management teachers do better.

TABLE IX. RELATIONSHIP BETWEEN INFORMATION ABILITY AND TEACHERS' TEACHING EXPERIENCE

\begin{tabular}{|c|c|c|c|c|c|c|c|c|}
\hline \multirow[t]{2}{*}{$\begin{array}{c}\text { Information } \\
\text { ability }\end{array}$} & \multicolumn{2}{|c|}{$\begin{array}{c}\text { experience of } \\
1-3(\%)\end{array}$} & \multicolumn{2}{|c|}{$2-7(\%)$} & \multicolumn{2}{|c|}{ 8-12 } & \multicolumn{2}{|c|}{ >13years } \\
\hline & can & desired & can & desired & can & desired & can & desirec \\
\hline $\begin{array}{l}\text { network } \\
\text { platform } \\
\text { using }\end{array}$ & 88.5 & 3.8 & 75.6 & 2.4 & 64 & 4 & 55.6 & 5.6 \\
\hline Database & 8 & 48 & 10 & 25 & 0 & 45.8 & 25 & 18.8 \\
\hline Excel & 75 & 16 & 50 & 15.8 & 65.9 & 20 & 52.9 & 11.2 \\
\hline $\begin{array}{l}\text { audio and } \\
\text { video }\end{array}$ & 46.3 & 25 & 15.4 & 46.2 & 21.7 & 34.8 & 16.7 & 33 \\
\hline
\end{tabular}

From the perspective of the difference of teaching experience, not only in commonly used office software skills, audio and video files recording and editing, designing of animations, but also in network using, teachers with an experience of 1-3 or 8-12 years do better than those of establishment and use of a small database, teachers with more than 13 years teaching experience do the best, while teachers of 8-12 years have the poorest performance but with the strongest desire to learn.

TABLE X. RELATIONSHIP BETWEEN INFORMATION ABILITY AND EDUCATION

\begin{tabular}{c|cllll}
\hline information ability & \multicolumn{2}{|c}{ bachelors } & \multicolumn{2}{c}{ masters } \\
& can & desired & can & desired \\
\hline Fetion or QQ network platform & 69.6 & 0 & 84.8 & 4.7 \\
$\quad$ using & & & & \\
Database & 13.6 & 22.7 & 8.5 & 37.8 \\
$\quad$ Excel & 31.8 & 18 & 60 & 15 \\
audio and video & 22.7 & 18.1 & 24.7 & 42 \\
Network information searching & 47.8 & 4.3 & 53.6 & 14.3
\end{tabular}

From the perspective of education, masters do better than bachelors in commonly used office software skills, network using, audio and video files recording and editing and in designing of animations. But in establishment and application of database, graduates do better than postgraduates, and these graduates are mainly from those with long teaching experience, while postgraduates have a stronger desire to improve their ability in such field.

TABLE XI. RELATIONSHIP BETWEEN INFORMATION ABILITY AND PROFESSIONAL TITLES

\begin{tabular}{|c|c|c|c|c|c|c|}
\hline \multirow[t]{2}{*}{$\begin{array}{c}\text { information } \\
\text { ability }\end{array}$} & \multicolumn{2}{|c|}{$\begin{array}{c}\text { Assistant } \\
\text { professors } \\
(\%)\end{array}$} & \multicolumn{2}{|c|}{$\begin{array}{c}\text { lecturers } \\
(\%)\end{array}$} & \multicolumn{2}{|c|}{$\begin{array}{c}\text { professors } \\
(\%)\end{array}$} \\
\hline & can & desired & can & desired & can & desired \\
\hline $\begin{array}{c}\text { network } \\
\text { platform } \\
\text { using }\end{array}$ & 92.6 & 0 & 82.8 & 5.1 & 66.7 & 4 \\
\hline Database & 7.6 & 46.2 & 7.2 & 36.4 & 17.4 & 17.4 \\
\hline Excel & 72 & 20 & 43.4 & 18.9 & 62.5 & 4.1 \\
\hline Animation & 25.9 & 48.1 & 5.5 & 45.6 & 25 & 33 \\
\hline $\begin{array}{l}\text { audio and } \\
\text { video }\end{array}$ & 40 & 28 & 20.8 & 41.5 & 16 & 36 \\
\hline
\end{tabular}

In the aspects such as commonly used office software skills, network using, audio and video files recording and editing and designing of animations the more primary the teachers' professional titles are, the stronger their information capacity is. But in establishment and application of database, professors are far better than the groups of assistant professors and lecturers.

Findings
Survey on the information technology ability and related interviews show that, teachers do better in two aspects of commonly used basic office software and network communication platforms, while teachers are weak in the video and audio file recording and editing, animation designing, establishment and application of database. But what they want to learn most is animation dfor the teachers involved think animation can not only be used in their work but also in their life, therefore to add fun and actually to enrich their real life.

As for the professional difference, management participants enjoy relatively advanced professional titles, so they do better in such more advanced information technology as establishment and application of database and statistic using of Excel. And in this part, teachers with advanced titles and experience of more years perform better, so it is concluded that the skills on more advanced information technology comes from teachers' need and practice in their practical work

And, another survey on students about their using of network and computer for study purpose shows that the extent of their using of such modern informational technology doesn't necessarily goes with, even hinders insignificantly, the improvement of their language proficiency, which suggests that at present students are likely to be lost in the wealth of information, so there is an urgent need for teachers guidance.

As for the way of training, the favorite one is full-time one, for one thing, teachers have to do much routine work, leaving no more time for further improvement of their skills, for another, they think the information technology is hard to learn be themselves, and it can only be obtained under experts' guidance. The third comes online training, which shows network plays a more and more important role in our work. And actually, the following interviews with these teachers find teachers with the advanced information technology capacity confess that their capacity is enhanced gradually by some practical research work.

\section{SUGGESTIONS}

Based on the above investigation and analysis, suggestions are given to the universities or institutions. One is to arrange some full-time training in groups if possible and the topic can include theory and practice, the technology and its application. A second is to give full play to the drive function of teachers with advanced professional titles and technical capacity, and with more experience. A third one is to add some related subjects to postgraduates' courses, to improve their information capacity as soon as possible so as to better serve the teaching and researching in their future work.

\section{REFERENCES}

[1] Nan Guonong. How to understand the information technology and teacher quality [J] Modern Distance Education, 2013.1,3 6.

[2] Nan Guonong. Reconstruction of the theoretical system of Educational Technology: the roadmap [J]. modern educational technology, 2010.4, 5-7.

[3] Gou Xue Rong. maturity model of University Teachers' educational technology ability [J]. 2012 August, 102-108.

[4] Zhang Li. analysis of the restricting factors of information literacy of teachers [J]. Journal of Jiangxi Institute of Education. 2012 June, 82-85. 
[5] Wang Qinglin. Thinking on how university teachers adapt to the development of education information [J]. Journal of Yangzhou University, 2012 August, 62-65.

[6] Chen Kaiquan. The difficulties and Countermeasures of University Teachers' teaching development: perspective of information and learning science $[\mathrm{J}]$, Journal of distance education, 2012 October, 24-30.

[7] Lu Hongxia. Exploration on the mode of the cultivation of information technology of teachers $[\mathrm{J}]$. value engineering, 2012 March, 284-285.
[8] Fu Zhongyong, Li Sijia. Development of Development and misunderstanding of informationization teaching ability of teachers [J]. Beijing College of Polotics and Law, 2012.3,112116.

[9] Fang Mingiian. A study of Principle and. model of information ability of teachers based on adult learning theory $[\mathrm{J}]$. modern education technology 2012.10, 33-36.

[10] Wang Wenjun, Wang Weijun. Practical analysis of teachers' information ability [J]. modern distance education, 2012.3, 6774. 